\title{
DEMANDAS DO PRESENTE: "TRADUZIR-SE”, DE FERREIRA GULLAR
}

\author{
Sandro Adriano da Silva* \\ Universidade de São Paulo \\ Faculdade Estadual de Ciências e Letras de Campo Mourão
}

\begin{abstract}
Resumo: O poema "Traduzir-se", de Ferreira Gullar, pode ser tomado como exercício líricoexistencial, cuja elaboração estética articula metáforas sintomáticas de uma subjetividade cindida. A economia estética do poema ensaia uma arquitetura do desejo em "traduzir-se", que manifesta a perplexidade do sujeito lírico diante do descentramento dessa experiência de "vertigem" e põe em suspeição sua tradução possível como arte. Neste artigo, apostamos em uma interpretação que considera rentável uma aproximação entre literatura e alguns pressupostos da psicanálise e da teoria e crítica de poesia, a fim de lançar um horizonte de compreensão sobre a emblemática poesia de Ferreira Gullar. O poema alude a uma autorreferencialidade do eu lírico e de suas marcas narcísicas, delineia um horizonte de ordem intersubjetiva, no qual se vislumbra um potencial alteritário do sujeito lírico, a emergência de uma subjetividade que se prenuncia híbrida, conflituosa: o eu poemático é gestado e ganha contornos existenciais num drama de linguagem. Uma "tradução" sempre contemporânea.
\end{abstract}

Palavras-chave: Poesia. Subjetividade. Ferreira Gullar.

"Não se diga, que é parte, sendo todo." Gregório de Matos

\author{
TRADUZIR-SE \\ Uma parte de mim \\ é todo mundo: \\ outra parte é ninguém: \\ fundo sem fundo. \\ Uma parte de mim \\ é multidão: \\ outra parte estranheza \\ e solidão. \\ Uma parte de mim
}

\section{(1) $(\Theta \Theta$}

BY NC ND Esta obra está licenciada sob uma Licença Creative Commons.

\footnotetext{
* Doutorando em Literatura Brasileira na Universidade de São Paulo, Mestradp em Letras pela Universidade Estadual de Maringá, Especialização em História e Cultura Afro-brasileira e Africana - União Pan-Americana de Ensino, graduação em Letras Português-Inglês pela Universidade Estadual do Oeste do Paraná e professorAssistente do Departamento de Letras da Universidade Estadual do Paraná - UNESPAR/FECILCAM, campus de Campo Mourão/PR.
} 


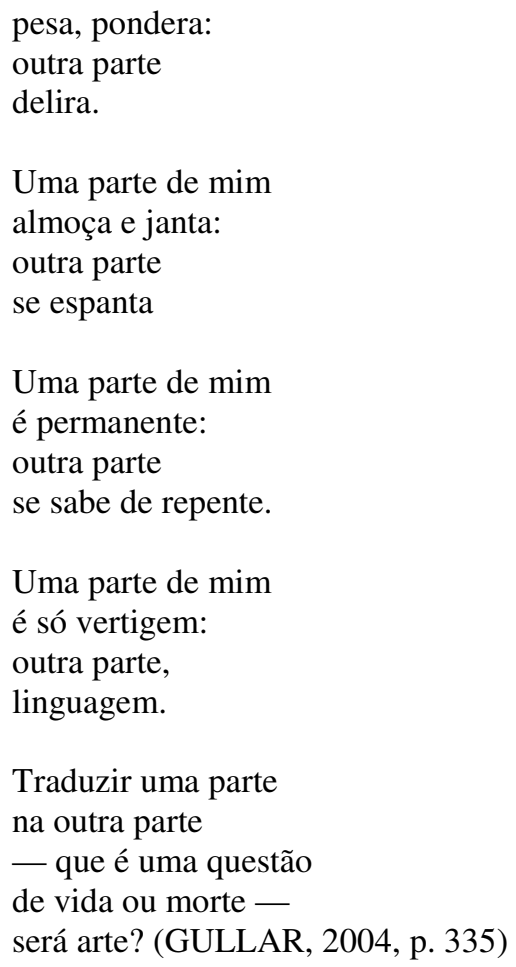

Em seu ensaio Roteiro do poeta Ferreira Gullar (2003), Alfredo Bosi, aponta nele uma "secreta coerência de seus temas, imagens e afetos" e uma forma de "situar-se entre os objetos da cultura" de modo a construir um "sentimento vivo de um tom, a visão de uma paisagem estilística, a identidade de um rosto" (p.171), sem, contudo, desconsiderar este roteiro como uma experiência literária que se renovou continuamente. O crítico sintetiza o percurso estético e político do poeta, que se efetua entre a estreia dos livros A luta corporal (1954), caracterizado por uma aderência ao experimentalismo, sobretudo neoconcreto; a passagem pelo neorrealismo de Romances de cordel (1962-69) e o memorialismo engajado e febril dos anos 1960/70 com “O poema sujo", período em que, perseguido pela ditadura militar, o poeta exilou-se do Brasil.

Bosi (2000) já havia destacado o "relevo dado ao esforço construtivo, à invenção do poema" (p. 473), como traço da poesia de Gullar. Sob o emblema de uma poesia participante, o crítico via em Gullar um "autor in progress" (p.473) - afirmação ponderada pelo reconhecimento de uma poesia cujo "roteiro já permite detectar um estado de alta tensão psíquica, e ideológica que nem sempre se resolve na aturada diligência formal” (p.473).

João Luis Lafetá, no consagrado ensaio Traduzir-se: ensaio sobre a poesia de Ferreira Gullar ([1980]1996), surgido logo após a primeira antologia do poeta, Toda poesia ([1980]2004), mapeia todo um itinerário, no qual, segundo o crítico, "somos levados a enxergar não apenas os reflexos de nossos movimentos literários, mas também os signos de diferentes movimentos políticos e sociais" (p. 115). Destacando o "virtuosismo estilístico de 
longo fôlego" (p.121) e a aproximação a uma definição clássica de lirismo em que pese a "subjetividade crispada face às dores da vida" (p. 124), Lafetá endossa uma concepção crítica que se acercará da poesia de Gullar, desde o juízo expresso por Sérgio Buarque de Holanda na "Introdução" de Toda poesia, segundo o qual, "a voz pública não se separa em momento algum de seu toque íntimo". Para Lafetá, a dicção gullariana inerva "uma linguagem que equilibra rigorosamente a liberdade individualista da expressão e a necessidade socializante de comunicação" (p.122, grifos nossos), que forjam, "através de uma pesquisa poética, uma identidade pessoal que, por sua vez, retira força e substância de uma identidade cultural.” (p. 125-126).

Outra menção esclarecedora sobre a lírica de Gullar vem do ensaio A luz da palavra suja ([2002]2005), de Ivan Junqueira, que põe em evidência a ruptura estética operada pelo poeta que, segundo o crítico, "busca surpreender a palavra naquela região em que esta se liberta de seu sentido canônico, ou seja, de sua sacralidade dicionária.” (p. 361). Essa busca, entretanto, não corresponde, para Junqueira, àquela "obsidiante busca no novo, da conquista do novo a qualquer preço, do novo pelo novo, [...] trata-se, entenda-se logo, de se despojar do ranço aquilo que é velho [...] para poder enxergar o que o tempo presente descortina" (p.363). A verve poética de Gullar, gestada entre "o instrumento da razão" e o "vívido sopro da emoção" (p.379), aponta, na visão do crítico, para a "implacável imagem especular de si mesmo, sujo como a sujeira da vida, cuja luz cintila entre as viscosas e abjetas entranhas da existência" (p. 377), em consonância com a autocrítica do poeta, para quem "a palavra que forma o poema sempre foi, no meu entender, uma entidade viva, nascida do corpo, suja sabese lá de que insondáveis significados" (GULLAR, 1989, p.25).

As considerações da crítica ao roteiro poético gullariano parecem aventar um horizonte comum, qual seja, a de uma incessante tentativa de "tradução" entre experiência estética e estética da experiência, na medida em que essa via dupla projeta-se como caminho possível para tentar-se uma leitura compreensiva da poesia (e da metapoesia) do autor. A partir desse caminho, propomos uma leitura do poema "Traduzir-se", inserido, primeiramente, no livro Na vertigem do dia (1980), tomando-o como metáfora de exploração de algumas dicotomias que espraiam essa experiência, sobretudo os liames sugeridos entre consciente/inconsciente, racional/irracional, expressão/comunicação, propostos no texto, e que nele propõem um enigma caro à arte e à vida e a sua "tradução". 


\section{Poética do descentramento}

"Deixo cair da mão o verso que se parte."

Dante Milano

Como procedimento, a tradução implica um movimento constante, de passagem, de trânsito entre significantes, em busca de significado. Uma preocupação constante atravessa essa tarefa, na qual, dependendo do texto-matéria a ser traduzido, impõem-se dificuldades ou aporias: realizar uma tradução possível.

Um dos principais problemas, fruto de antigos debates, é expresso pelo também antigo adágio italiano "traduttore, traditore", (MILTON, 1998) ${ }^{1}$ que, num trocadilho, quer dizer que toda tradução implica uma traição. A tradução fica, nessa perspectiva, às voltas com a "traição", rumor da língua/linguagem, como dinâmica que rubrica nuances do registro de um universo linguístico para outro, denotando, não raramente, uma "impossibilidade da tradução poética" (PAZ, 1982, p.55), como na busca idealista e utópica de Pierre Menard, autor del Quijote, de Borges, em que o protagonista aventava poder traduzir fidedignamente ou literalmente, do espanhol para o francês. (BORGES, 2001, p. 53-64). Essa impossibilidade se dá devido ao caráter ambíguo do texto escrito, a um só tempo individual, único, e rizomático, plástico, plurívoco. Paz (1971) salienta que "cada texto es único y, simultáneamente es la traducción de outro [...]es ya una traducción: primero del mundo noverbal y, después, porque cada signo y cada frase es la traducción de otro signo y de otra frase. (p. 9). ${ }^{2}$

No poema de Gullar, o mote da tradução elabora um conjunto metafórico: o título reivindica uma hermenêutica de si. Hermēneuein 3 significa "declarar", "anunciar","interpretar", "esclarecer" e, por último, "traduzir". "Traduzir-se" - o uso da partícula "se", funciona como uma licença poético-gramatical (incorpora um caráter reflexivo) - denota um debruçar sobre si, ato, portanto, de auscultamento do ser, de um encontro consigo mesmo, fundante de uma experiência de transcendência com/na palavra matéria-prima da poesia e do conhecimento, pois "pela palavra, o homem é metáfora de si mesmo" (PAZ, 1982, p. 43, grifo nosso). Essas palavras estão “impregnadas de vida e de experiências, [...] o que implica "uma consciência que transcende o dado emocional, que ultrapassa até, minha capacidade conceitual.[...] (GULLAR, 1998, n.p.). O poeta, entretanto,

\footnotetext{
${ }^{1}$ MILTON, John. Tradução: teoria e prática. São Paulo: Martins Fontes, 1998.

${ }_{3}^{2}$ PAZ, Octavio. Traducción: literatura y literalidad. Barcelona: Tusquets Editor, 1971.

3 CEIA, Carlos. E-dicionário de termos literários. Disponível em: http://www.edtl.com.pt/index.php?option=com_mtree\&task=viewlink\&link_id=232\&Itemid=2. Acesso em 10 abr. 2013.
} 
"é contra a palavra", [...] uma vez que "a poesia é processo de desaparecimento da palavra" [...] atua, paradoxalmente, "para apagar a palavra. Porque a palavra é matéria, e a poesia é arte" (1999, n.p.).

O poema alude a uma autorreferencialidade do eu lírico, metáfora de marcas narcísicas, delineia um horizonte de ordem intersubjetiva, no qual se vislumbram duas questões: a primeira, mais evidente, o potencial alteritário do sujeito lírico, ou para retomar Octavio Paz (1982, p. 319), de outridad, qual seja, a capacidade de o poema lançar um olhar mais amplo, de diálogo com o mundo, aventando uma dimensão ética -; a segunda, apenas esboçada, no final do texto, e que põe, tacitamente, em suspenso, algumas demandas em torno da essência e condição da arte.

Ainda sobre a pregnância do sentido de "traduzir-se", podemos considerar a emergência de uma subjetividade que se prenuncia híbrida, conflituosa: o eu poemático é gestado e ganha contornos existenciais num drama de linguagem. $\mathrm{O}$ encontro com o próprio poema produz a centelha de reescrita do texto no texto da vida, como diz a lição de Barthes (1989 apud SCHOLES, 1991, p.17). Operação de linguagem, "traduzir-se”, aqui, corporifica e transgride os liames impostos por uma estrutura que, como veremos, se difrata - experiência paradoxal, antinômica, em que o eu lírico encontra o limite e a transgressão como condição imanente (texto-composição) e latente (ressonâncias do desejo, da falta, do trágico, dada a consciência de precariedade da linguagem, sugerida pelo eu lírico). Em sua totalidade, o poema é uma acurada experiência de confessional, estetização de um descentramento existencial, de uma “despossessão de si”, em linguagem psicanalítica (BIRMAN, 2001, p. $45)$.

A ocorrência do verbo traduzir dá-se em duas situações distintas: a primeira, no título, ao qual já nos referimos, mas que vale considerar, ainda, a escolha por um verbo "acidentalmente pronominal", segundo uma concepção gramatical mais prescritiva, tem o sentido de "revelar-se", "manifestar-se" (HOUAISS, p.726;), e que do ponto de vista de uma pragmática, é pouco usual, posto que o verbo é essencialmente pronominal (ALMEIDA, 1986). A segunda ocorrência apresenta o verbo "traduzir" no infinitivo, e caracteriza um deslocamento da relação do sujeito lírico e sua trajetória, sua tentativa de tradução - o verbo, nessas condições, exprime um fato sem referência ao sujeito (LUFT, 2008, p. 509).

De um ponto de vista, segundo o qual o objeto estético "constitui-se a partir de um conteúdo artisticamente formalizado (ou de uma forma artística plena de conteúdo)” (BAKHTIN, 1998, p. 50, grifos do autor), pode-se dizer que o poema articula uma enunciação 
lírica de acento agônico e uma arquitetura poética rígida, cujo resultado desvela/matiza aquela dicotomia nietzschiana, em que a essência da arte se radica na duplicidade dos sentidos apolíneo e dionisíaco.

O primeiro corresponde, no poema, ao rigor formal do texto, seu caráter figurativo, escultórico, de concepção cubista ${ }^{4}$ : as sete estrofes correspondem a uma decomposição do poema em partes, em planos sucessivos, superpostos, procurando a visão total da figura, ângulos distintos, no mesmo instante, de forma fragmentada. O segundo é dimensionado pelo mapeamento da pulsão de eros que, aqui, confere uma articulação poético-existencial, quer pela demanda de afeto, inventariada pela solidão e medo ancestrais, pelo pressentimento de desordem da alma e pela indagação se isso, "que é uma questão de vida ou morte", pode ser arte; se o sendo, como o a arte pode ser uma tradução possível, uma transcendência pelo belo.

Uma das chaves de abertura para a inteligibilidade do poema pode ser tomada do recurso da anáfora como um expediente rentável na economia do texto. Dada a sua recorrência ao longo de seis das sete estrofes, ela se caracteriza como "anáfora insistente" (GUIRAUD, 1970, p. 45); e alterna-se entre "anáfora gramatical” (quando garante a repetição do sintagma "Uma parte de mim é"/"outra parte é") e "anáfora semântica" (ao retomar a expansão sintagmática anterior: "traduzir uma parte/na outra parte). A partir de Greimas e Courtés (1993) poderíamos ainda considerar aqui "uma relação anafórica formal entre dois termos" ("Uma parte de mim éloutra parte é $\leftrightarrow$ traduzir uma partelna outra parte) em que "um dos quais está presente ou atual, estando o outro ausente, em outro local, ou sendo passado: nesse sentido, poder-se-á falar de anáfora cognitiva.” (p.19).

A sutileza desse procedimento estilístico ressoa como demanda de conhecimento e representação: todo o poema é concomitantemente descrição e narração de um eu lírico que intenta "traduzir" sua tentativa de compreensão da transitividade que marca a dinâmica de referências e integração que o constituem, expressas pelo jogo metonímico e pelo efeito de oximoros, derivados do nível lexical: todo mundo/ninguém, fundo sem fundo/ multidão, estranheza, solidão, pesa/pondera, delírio, almoça/janta, espanta, permanência/de repente, vertigem/linguagem. $\mathrm{O}$ recurso anafórico estabelece um fluxo rítmico ao poema, configurando seu pathos, à amplificatio afectiva, "na medida em que, em relação ao conteúdo de palavra, a

\footnotetext{
${ }^{4}$ Para um levantamento acurado das correspondências entre a poesia de Ferreira Gullar e as artes visuais, desde as concepções que o poeta elabora sobre arte e estética, e suas implicações no processo de criação do discurso poético ver: FINKLER, Gredes Rejane. O resgate da poética do pensamento em Ferreira Gullar e em Luis Felipe Noé. 2004. 297f. Tese (Doutorado em Letras) - Universidade Federal do Rio Grande do Sul. Instituto de Pós-graduação em Letras. Porto Alegre, 2004.
} 
repetição traz consigo um enriquecimento afectivo" (LAUSBERG, 2004, p. 156), pela ênfase que engendra no discurso.

Mahony (1990), ao estabelecer uma relação entre psicanálise e discurso estético, referindo-se à poesia e elencando a "repetitividade", lembra que "o poeta se esforça [...] em recriar a linguagem, em estabelecer um laço necessário e motivado entre o significante e o significado" (p. 75, grifos nossos). Dessa forma, na repetição, diz a letra freudiana, "o sujeito vive [o que repete], algo real e atual, sem saber que o passado é uma força atuante." (FREUD, [1914] 1969, p. 105). É um conceito utilizado para a compreensão de sintomas e processos inconscientes, mencionada ao longo de toda a teorização da Psicanálise, ${ }^{5}$ correspondendo a uma pulsão mortal e desesperadora, que insiste em se apresentar no seu trajeto rumo à satisfação, à manutenção, portanto do princípio de prazer (GARCIA-ROZA, 166, p. 139).

Gilles Deleuze (1988), com um enfoque traçado a partir da filosofia da diferença, afirma que "o artista não opera pela repetição sob o signo do idêntico [...] ela expressa [...] uma instantaneidade contra a variação, uma eternidade contra a permanência. Em todos os sentidos, a repetição é transgressão". (p.24). Segundo Deleuze, não há identidade fixa, e a repetição, nunca temos como resultado algo idêntico ao original; mesmo na cópia há diferença, há o novo; o evento repetido é radical e paradoxalmente novo.

O circuito poético-existencial é repertoriado, de um lado, pelo dilema narcísico, na medida em que corresponde à mobilidade do afeto/pathos da experiência de busca; e, de outro, pela "despossessão de si", uma vez que "afogado pelo excesso intensivo, enfim, o sujeito não se reconhece mais nos seus referenciais identificatórios." (BIRMAN, 2001, p. 46). A predileção pelo verbo ser atribui uma semântica existencial que é subsumida pelo valor de transitividade da despersonalização marcada pela metáfora da "estranheza".

Estranhamento que pode ser remetido a uma categoria de análise no fenômeno da linguagem, tal como se apresenta no formalismo russo, em que um efeito de distanciamento é operado em relação ao modo comum como apreendemos o mundo, o que nos permitiria entrar em uma dimensão nova, só visível ao olhar estético, como propõe Chklovski (1976), ao afirmar que "para desenvolver a sensação de vida, para sentir os objetos, para provar que pedra é pedra, existe o que se chama arte" (p. 18). Como instrumento de percepção, "a arte se serve de dois procedimentos: o estranhamento e a complicação da forma" (p.45). Localizado, portanto, na distinção entre o reconhecimento e percepção desautomatizada, o estranhamento

\footnotetext{
${ }^{5}$ No espaço delimitado deste texto, não cabe uma extensa explanação do conceito de "repetição" e sua evolução na teoria psicanalítica. Remetemos o leitor a dois textos fundamentais, em que o conceito é elaborado sob diferentes formulações teóricas: Recordar, repetir e elaborar (1914) e Além do princípio do prazer (1920).
} 
singulariza o objeto artístico, por meio de procedimentos estéticos que operam deslocamento e imprevisibilidade, em que "outra parte/ se sabe de repente", portanto "intencionalmente removido do âmbito da percepção automatizada" (p.12).

O estranhamento guarda uma relação com o incognoscível, com o fascínio e a sedução; deita suas raízes em Platão, sobretudo na obra A República (1959), que não permitiu que as artes, principalmente as artes plásticas, fizessem parte da polis grega, por perceber nela o aberto da poética como um lugar de desamparo, onde nada mais pode ser respaldado pela razão, motivo pelo qual as artes eram causa de estranhamento.

A ideia de estranhamento também atravessa a modernidade, fornecendo as justificativas da impossibilidade em descrever a experiência da arte e do belo com os conceitos herdados da tradição, como aponta Friedrich (1978), ao concluir que "esta junção de incompreensibilidade e de fascinação pode ser chamada de dissonância, pois gera uma tensão que tende mais à inquietude que à serenidade" (p.15). O estranhamento coloca-se como metáfora de dizer o indizível e o interdito, de lidar com a densidade humana "onde se situa o valor do Belo, [e que] abriga a inquietante estranheza de tudo aquilo que deveria permanecer secreto e oculto, mas que vem à luz” (FRANÇA, 1997, 131).

Nesse sentido, "Traduzir-se" reverbera um diálogo com a modernidade, na medida em que faz uma referência à clivagem do eu lírico, à ruptura em si mesmo, de "protesto contra uma situação social que cada indivíduo experimenta como hostil, estranha, opressiva", uma “forma de reação à coisificação do mundo", (ADORNO, 2003, p. 68,75, 80, grifo nosso), pelo mergulho nele [no poema], descobrindo o subjacente, o ainda não captado" [...] constituindo, assim, "o paradoxo básico da lírica - ser subjetividade objetivada" (KOTHE, 1978, 166). A metástase do eu lírico, portanto, é sintoma de modernidade na medida em que a rarefação de uma subjetividade unitária de contornos definidos se debate com os antagonismos, como aponta Ginzburg, ao afirmar que lírica, ao elaborar o choque, evoca "o necessário estranhamento que deve reger as condições da realidade social, uma vez que esta se constitui como antagônica, dotada de impasses não resolvidos que se potenciam constantemente" (GUINZBURG, 2003, n.p.).

Em Freud, ([1919]1976), o estranhamento, (Das Unheimlich), "se apresenta como um sentimento estranho, cuja sensação não é nada nova ou alheia, porém algo que é familiar e há muito estabelecido na mente, e que somente se alienou desta através do processo da repressão." (p. 284). Segundo Freud, "Schelling, já advertira, Unheimlich é tudo o que deveria ter permanecido secreto e oculto, mas que veio à luz." (p. 284). De acordo com França 
(1997), o conceito de estranhamento foi colocado como "um ramo central da estética", indicando que o belo opera como lugar de equívoco, porque oculta e desvela o horrível em um só tempo. A estranheza inquietante "vem afirmar que nada se parece mais íntimo de nós do que aquilo que é mais estranho" (p. 132). Tal "sensação de uma desconfortável “inquietude", "vertigem do informe e do absurdo" (PICON, 1969, p. 22,26) funde o estético e o agonístico (BLOOM, 1995, p.16), conquanto "nesse sentido, a linguagem esquizofrênica guarda uma interessante semelhança com a poesia." (EAGLETON, 2006, p. 239).

Segundo Blanchot (1987), a literatura faz muito bem isso, ela parece ter como missão marcar terminantemente esse lugar de impasse a fim de testemunhar a indizibilidade do horror, do estranho, dessa sombra da realidade que se instala em toda a arte. A literatura, por sua vez, apresenta-se como fundadora de sua própria realidade e atribui a essa realidade um caráter especificamente ambíguo, obscuro e enigmático. Ela passa a ser promotora de estranhamento, essa sensação de que se prefere falar de um lugar que está além ou à margem do mundo, ao abandono.

Paradoxal por excelência, a segurança das assertivas marcadas pelo verbo ser, vão, aos poucos, revelando metáforas de perda, desmoronamento e expectação numa cadência que caracteriza a verticalização do poema (fundo-solidão-delira (por perífrase, "delírio)-espanta (por perífrase, “espanto)-de repente (por perífrase, "repentinamente")-linguagem (por metonímia)-Arte (também por metonímia). Essa cadeia é índice da logicidade da estrutura poemática, rígida até o ponto de precipitação no "delírio", esse "núcleo de verdade" que "funciona para atingir uma obliteração do inconsciente que ele se esforça em encobrir", e pelo qual "a relação do velar-desvelar do inconsciente deixa se prende à eficácia literária" (GREEN, 1983, p. 261; 217).

Recorrendo a metáfora que sugere dispersão, queda e aniquilação (mundo, ninguém, fundo sem fundo, multidão, estranheza, delírio etc.), o eu lírico projeta uma identificação e solidariedade com o mundo, sem, com efeito, encontrar nela uma saída existencial. Há nessa imagem uma ressonância intertextual com Baudelaire, para quem "- Hélas! tout est abîme”/ "tudo é abismo" (BAUDELAIRE, 1985, p. 175) e, na cartilha da modernidade, quando o poeta encontra esse abismo da linguagem é que pode, de fato, escrever, uma vez que para ele, "Multidão,/solidão: termos iguais e permutáveis para o poeta activo e produtivo" (BAUDELAIRE, 1968, p.243).

"Traduzir-se" formula uma poética de risco: encontrar a síntese sujeito lírico alijado de sua unidade original e forma poética convincente, aquele "fruto do cálculo" aliado a uma 
“experiência de abandono" (PAZ, 1982, p. 15), capaz de garantir a "função mais nobre da poesia, libertar no sentimento e não do sentimento" (HEGEL, 1980 p. 105). O poema também remete àquele princípio poético de Paul Valéry (2007) segundo o qual a arte deveria ser "fundada sobre a inteligência [...] isto é, não excluindo os inconscientes (o que não faria sentido), mas os evocando [...] segundo a ocasião; e sobretudo os provocando, assinalandolhes os problemas". (1973, p. 336, grifos nossos). ${ }^{6} \mathrm{Na}$ lição valeryana, o poema requisita uma construção consciente, intelectualizada, cujo ideal é a poesia pura, que, com efeito, irrealizada, é sempre deveniente; dessa forma, poesia e desejo estabelecem uma relação de coetaneidade.

Freud ([1907] 1980, p. 18) fala do poeta como auscultador da psique, a fonte de um conhecimento particular que se traduz em sintoma; uma aletheia, uma "verdade do desejo , pois o texto concerne ao desejo de escrever [...] longínquo substituto de um desejo de ver e de saber"; uma "verdade do fantasma que habita o texto, que faz do texto o pré-texto do fantasma", comum ao autor e ao leitor, pois "o texto é um objeto trans-narcísico"; uma "verdade da ilusão", que confere a este ser de ficção [...] um valor ao qual se pode até mesmo sacrificar o real e o desejo de viver"; por fim, uma "verdade histórica", que faz do texto um produto da história daquele que o criou, que fala à história daquele que o consome" (GREEN, 1983, p. 216).

Sensação obscura de que, na linguagem poética, há um exercício de procura, de encontro e desencontro de algo fugidio, que escapa ao racional, "que desmascara o sujeito humano como fissurado e inacabado" a quem "a atitude estética, segundo ele, pode nos compensar pelos sofrimentos da existência, mas não pode proteger-nos deles" (EAGLETON, 1993, p. 193,196,). Tentativa de trazer ao plano da linguagem a imagem do desejo, na letra freudiana, vale lembrar, a fantasia poética é resultado de um investimento do desejo em "passagem à arte", "um ler-se a si mesmo", originado no "ganho de sedução", em que a condição da arte implica "reparação do objeto de amor" (BELLEMIN-NOËL, 1983, p. 34, 38, 46).

Lacan (1982) também aponta a intimidade entre poesia e desejo, posto que "el poeta da testimonio de una reacion profunda del deseo con el linguaje, al mismo tiempo que demuestra [...] hasta que punto esa reiación poética con el deseo se ve siempre dificultada cuando se trata de la pintura de su objeto" (p. 128). Afinal, como ensina Poe (2009) "um

\footnotetext{
${ }^{6}$ VALERY, Paul. Caheirs I. Choix de textes. Org. Judith Robinson-Valéry. Paris: Gallimard, 1973, tradução nossa.
} 
poema só é um poema na medida em que provoca um intenso entusiasmo na alma, elevandoa; e, por uma necessidade psíquica." (p. 217).

Um breve mapeamento de outros aspecto formais também sugerem essa tensão: o poema é constituído por um conjunto de seis quartetos e um quinteto, marcados por uma metrificação assimétrica (tri e heptassílabos); por rimas externas (mais recorrentes) e também internas (mim/ninguém). Ressalte-se a estilística fônica, dada a prevalência das assonâncias vocálicas, em que os sons oclusivos $[u]$ e $[0]$ que denotam, no texto, uma sensação de fechamento e escuridão contrapõem-se à reiteração das vogais [a] e [e], que denotam signo de abertura, expansão, movimento; por seu turno, a predileção pelas aliterações em [t], [d] e [p], além de outras, sugerem conflito e fragmentação, em um embate cujas ressonâncias compõem uma força obstaculizadora da relação do ser e da linguagem.

Essa relação, ao atribuir expressividade do material fônico, implica uma cadeia rítmica de um "traduzir-se" em revelação-auscultamento do eu lírico; ritmo marcadamente ondulatório, marcado também pelos enjembements, resultando em uma nítida linha de entonação agônica, como que a indicar que, malgrada a tentativa de "traduzir-se" o eu não é propriamente um lugar de desvelamento, de transparência, de fidedignidade na apreensão do fenômeno humano e poético.

Tal tentativa de tradução resulta, antes, na desmistificação do ideário de racionalidade, de negação do sujeito cartesiano. A geometrização do poema, a que já nos referimos, evoca uma imagem cubista, caracterizando, por si só, uma linguem icônica, portanto, uma representação do modo de olhar. Tentativa de visão do todo, numa imagem que se quer panóptica, mas que incorre na impossibilidade de legislar sentidos fixos, posto que, no final do poema, a estrutura marca uma rotura - os travessões funcionam como que disjuntores do tempo do poema, de sua unidade rítmica, operando uma digressão, uma inquietude; ao mesmo tempo em que inclui a assertiva da relação vida/morte no processo de tradução, não oferece uma conclusão objetiva, fugindo mesmo de todo resultado, numa pergunta retórica: "será arte?"

"pois vale o duplo de qualquer chama."

J.C. de Melo Neto

Modulado pela gradação, o eu lírico enunciado nesse "traduzir-se" é atraído por uma força avassaladora - de vida ou morte -, que não sabe definir se capaz ou não de transformarse em matéria de arte. Ao defronta-se com o abismo da linguagem, descobrindo-se só, tragicamente evolui da solidão para o delírio, deste para o espanto, e, por fim, numa epifania - que escamoteia o inventário da "vertigem", não a anulando de todo, mas pondo-a sem 
suspenso, ao dissolvê-la na "linguagem". Eterno retorno: exatamente a "linguagem" (gráfica, icônica, poética e existencial) arma a sutura total do poema e (des)territoraliza o eu poemático, remetendo, pela experiência de verticalidade, à imagem da queda.

Nesse conjunto de imagens animadas por um sentimento, parafraseando Croce, vale ressaltar, ao lado desse "sem fundo" (metonímia de vazio), a solidão. Blanchot (1987) fala de escrita como portadora (porta-voz?) de uma solidão - a "solidão da obra", que joga o "eu" para um vazio de onde emergem as linguagens, radicalizando transformação no sujeito, numa "experiência total” (p. 31). Nela, a dicção social também ecoa, uma vez que, para retomar Adorno (2003), na "própria solidão da palavra lírica" e na "densidade de sua individuação" (p. 70, 72), são interiorizados os impasses entre o eu e mundo.

A radicalidade dessa experiência - de poética e transcendência - lança um olhar sobre certos matizes da concepção da arte, redimensiona sua essência para uma zona de indiscernibilidade, de negação a qualquer sentido que repouse aprioristicamente em conceitos, o que não invalida, contudo, pela mesma estratégica retórica contida no verso "será arte?", sua natureza de "educação ao Fado e à morte", de que fala Eco (2003, p.21), e sua capacidade de pôr o eu e o mundo em causa, submetendo-o à prova da linguagem, pois "a literatura é o que interroga o mundo" (RICARDOU, 1968, p. 42).

"Traduzir-se", pois, implica, aqui, uma trans-formação da "matéria vertente" do horizonte de vivências na objectualidade do poema, processo que corresponde a um trabalho, portanto a uma techné - modo de realizar uma tarefa; e a uma ars, que denota "articulação" entre partes de um todo. Portanto, o silêncio que se segue à pergunta retórica que encerra o poema, "será arte?", em seu tom de suspeição/suspensão, indica um silêncio rentável, não de síntese, mas de uma tradução possível - que integra a experiência poética e a produção da subjetividade na rubrica das três vias incontornáveis de reflexão da estética: o fazer, o conhecer e o exprimir. "Questão de vida ou morte", o poema reitera a perplexidade diante do limite do belo, esse "princípio de espanto que mal conseguimos suportar, e ainda assim o admiramos porque sereno, deixa de nos destruir", de que fala Rilke (1989, p.45), ao mesmo tempo em que sugere a insubmissão da poesia a imperativos de comunicabilidade.

O "fechamento" arquitetural do poema fomenta sentidos à deriva: ao elidir os binarismos esquemáticos anteriores, inviabiliza qualquer possibilidade de síntese. Estagnado como "obra de escrita", especializado na folha, delimitado pelos recursos dos signos verbais, cria uma imagem contrastiva com sua abertura retórica, a matizar-se "obra em movimento", como fala Eco (1991, p. 51), sob a tutela da leitura. Negação de univocidade - selo da melhor 
poesia - o poema sugere a precariedade do intercâmbio entre a poeticidade latente (e, no limite, a Arte) e a linguagem manifesta. A permanente interrogação cria um pós-poema misto de enigma e insolvência, cuja decifração possível é também o devorar antigo e perpétuo dilaceramento do ser.

\section{Referências}

ADORNO, Theodor. Palestra sobre lírica e sociedade. In: . Notas de literatura I. Trad. Jorge M. B. de Almeida. São Paulo: Duas Cidades; Editora 34, 2003, p. 65-90.

ALMEIDA, Napoleão Mendes de. Gramática Metódica da Língua Portuguesa. São Paulo: Saraiva, 1986.

BAKHTIN, Michail Mikalovich. O discurso na poesia e o no romance. In: Questões de literatura e de estética: a teoria do romance. Trad. Aurora Fornoni Bernandini. 4. ed. São Paulo: Hucitec, 1998.

BAUDELAIRE, Charles. Les Foules. In Claude Pichois. Paris: Gallimard, 1968, p. 430.

Oeuvres completes. Org. Y.G. Le Dantec; As Flores do Mal. Trad., intr. notas Ivan Junqueira. Rio de Janeiro: Nova Fronteira, 1985, p. 175.

BELLEMIN-NOËL, Jean. Psicanálise e literatura. Trad. Álvaro Lorencini e Sandra Nitrini. São Paulo: Cultrix, 1983.

BIRMAN, Joel. Despossessão, saber e loucura. In: QUINET, Antonio. (Org.). Psicanálise e Psiquiatria. São Paulo: Marca d'Água Livraria e Editora, 2001.

BLANCHOT, Maurice. O espaço literário. Rio de Janeiro: Rocco, 1987.

BORGES, Jorge Luis. Pierre Menard, autor de Quixote. In: Ficções. Trad. Carlos Nejar. 3.ed. São Paulo: Globo, 2001, p. 53-64.

BOSI, Alfredo. História concisa da literatura brasileira. 37.ed. São Paulo: Cultrix, 2000.

Roteiro do poeta Ferreira Gullar. In: Céu, inferno: ensaios de crítica literária e ideológica. São Paulo: Duas Cidades; Editora 34, 2003, p. 171-186.

CHKLOVSKI, Viktor. A arte como procedimento. In: EIKHENBAUM, B. et al. Teoria da literatura em suas fontes: formalistas russos. Porto Alegre: Globo, 1976, p. 39-56.

DELEUZE, Gilles. Diferença e Repetição. Rio de Janeiro: Graal, 1988.

EAGLETON. Terry. O nome do pai: Sigmund Freud. In: A ideologia da estética. Trad. Mauro Sá Rego Costa. Rio de Janeiro: Jorge Zahar, 1993, p. 192-211.

A psicanálise. In: Teoria da literatura: uma introdução. Trad. Waltensir Dutra. 6. ed. São Paulo: Martins Fontes, 2006, p. 227-292. 
ECO. Umberto. Sobre algumas funções da literatura. In: Sobre a literatura. Trad. Eliane Aguiar. Rio de Janeiro: Record, 2003, p. 21.

FRANÇA, Maria Inês. Sobre a estética do desejo. In: Psicanálise, estética e ética do desejo. São Paulo: Perspectiva, 1997, p. 131-164. (Coleção Estudos).

FREUD, SIGMUND. Recordar, repetir e elaborar. (Novas recomendações sobre a técnica da psicanálise II) In: 1969, v. XII.

O estranho. In: Obras completas. Edição standard brasileira das obras completas de Sigmund Freud. Rio de Janeiro: Imago, 1976, v. XVII, p. 282-301.

. Delírios e sonhos na Gradiva de Jensen. In: Obras completas. Edição standard brasileira das obras completas de Sigmund Freud. Rio de Janeiro: Imago, 1976, v. IX.

FRIEDRICH, Hugo. Estrutura da lírica moderna: da metade do século XIX a meado do século XX. Tradução do texto por Marise M. Curioni; Trad. das poesias por Dora F. da Silva. São Paulo: Duas Cidades, 1978.

GARCIA-ROZA, Luiz Alfredo. O retorno do recalcado. In: Freud e o inconsciente. 18. ed. Rio Janeiro: Zahar, 2001, p. 151-169.

GINZBURG, Jaime. Theodor Adorno e a poesia em tempos sombrios. In: Alea: Estudos Neolatinos, Rio de Janeiro, v.5, n.1, jan./jul. 2003. Disponível em: http://www.scielo.br/scielo.php?script=sci_arttext\&pid=S1517-106X2003000100005. Acesso em 10 dez.2012.

GREEN, André. Literatura e psicanálise: a desligação. In: LIMA, Luiz Costa. (Org.). Teoria da literatura em suas fontes. 2.ed.rev.e ampl. Rio de Janeiro: Francisco Alves, 1983, p. 208236.

GREIMAS, Algirdas Julien; COURTÉS, Joseph. Dicionário de Semiótica. Trad. Alceu Dias Lima et al. 9.ed. São Paulo: Cultrix, 1993, p. 19.

GUIRAUD, Pierre. A Estilística. São Paulo: Mestre Jou, 1970.

GULLAR, Ferreira. Traduzir-se. In: Toda poesia. 12. ed. Rio de Janeiro: José Olympio, 2004, p. 335.

A reinvenção da poesia. In: Indagações de hoje. Rio de Janeiro: José Olympio, 1989, p.

Entrevista: Ferreira Gullar. Antonio Carlos Secchin, Adriano Espíndola, Ivan Junqueira et. Al. Poesia sempre. Rio de Janeiro: Fundação Biblioteca Nacional, ano 6, n. 9, mar. 1998. Disponível em: http://www.literal.com.br/ferreira-gullar/bio-biblio/sobreele/imprensa/entrevista-com-ferreira-gullar/. Acesso em: 22 jun. 2013.

A poesia que nasce do espanto. Entrevista a Tonico Mercador. A palavra. Belo Horizonte: Gaia, ano 1, n. 8, nov. 1999. Disponível em: http://www.literal.com.br/destaquemedio-home/ferreira-gullar-a-poesia-que-nasce-do-espanto/. Acesso em 22: jun. 2013.

HEGEL. A poesia. In: Estética: poesia. Lisboa: Guimarães editores, 1980. 
HOUAISS, Antônio. Minidicionário Houaiss da língua portuguesa. 2.ed. rev. e aum. Rio de Janeiro: Objetiva, 2004.

JUNQUEIRA, Ivan. A luz da palavra suja. In: Ensaios escolhidos - volume 1: de poesia e poetas. São Paulo: A Girafa Editora, 2005, p. 361-380.

KOTHE, Flávio. Benjamin e Adorno: confrontos. São Paulo: Ática, 1978.

LACAN, JACQUES. Las formaciones del Inconsciente. Buenos Aires, Nueva Vision, 1982, p. 128.

LAFETÁ, João Luiz. Traduzir-se: ensaio sobre a poesia de Ferreira Gullar In: $A$ dimensão da noite e outros ensaios. Rio de Janeiro: Duas Cidades, 1996, p.

LAUSBERG, Heinrich. Elementos de retórica literária. Trad. R. M. Rosado Fernandes. 5.ed. Lisboa: Fundação Calouste Gulbernkian, 2004.

LUFT, Celso Pedro. Dicionário prático de regência verbal. 1. ed. São Paulo: Ática, 2008.

MAHONY, Patrick. Psicanálise e discurso. Trad. Raul Fiker e Ricardo Pinheiro Lopes. Rio de Janeiro: Imago,1990. (Coleção Nova Biblioteca de Psicanálise).

MILTON, John. Tradução: teoria e prática. São Paulo: Martins Fontes, 1998.

NIETZSCHE, Friedrich. O Nascimento da Tragédia ou Helenismo e Pessimismo - 1872. Notas, Tradução e Posfácio, Jacó Guinsburg. 1. reimpr. São Paulo: Editora Schwarcz, 1992.

PAZ, Octavio. Traducción: literatura y literalidad. Barcelona: Tusquets Editor, 1971. O arco e a lira. Trad. Olga Savary. Rio de Janeiro: Nova Fronteira, 1982.

PICON, Gaëtan. O escritor e sua sombra. São Paulo: Editora Nacional; Editora da USP [1969]. (Biblioteca Universitária. Série 5. Letras e Linguística, v.2).

PLATÃO. A república. São Paulo: Atena, 1959.

POE, Edgar Allan. A Filosofia da composição. In: Obras completas. Tradução, introdução e notas de Margarida Valle de Gato. Lisboa: Tinta-da-China, 2009, p.217.

RICARDOU, Jean. Que pode a literatura?. Lisboa: Editorial Estampa, 1968, p.42.

RILKE, Rainer Maria. Quem das legiões de anjos? (Primeira Elegia). In: Sonetos a Orfeu e Elegias de Duíno. Edição Bilíngue. Trad. Emmanuel Carneiro Leão. Petrópolis/Rio de Janeiro: Vozes, 1989, p.45.

SCHOLES, Robert. Protocolos de leitura. Lisboa: Edições 70, 1991.

VALERY, Paul. Caheirs I. Choix de textes. Org. Judith Robinson-Valéry. Paris: Gallimard, 1973.

VALÉRY, Paul. Variedades. São Paulo: Iluminuras, 3. reimpr., 2007. 
[Recebido em junho de 2013 e aceito para publicação em outubro de 2013]

\section{Demand present: Traduzir-se, by Ferreira Gullar}

Abstract: The poem "Translate to" by Gullar, can be taken as lyrical existential exercise where the preparation is divided into aesthetic metaphor-symptom of a split subjectivity. The aesthetic economy of the poem rehearses an architecture of desire to "translate" that expresses perplexity of the lyrical subject before the overthrow of this experience of "vertigo" and puts suspicion on his translation possible in art. In this article, we bet on an interpretation that considers an approximation profitable between literature and some assumptions of psychoanalysis and the theory of poetry and criticism, to launch a horizon of understanding that this is touted as one of the most iconic poems Gullar. The poem alludes to a selfreferentiality of the lyrical self and its brands narcisistic, outlines a horizon of intersubjective order, in which one sees a potential altering the lyrical subject, the emergence of a subjectivity that foreshadows hybrid conflict: the self is gestated poetic and is outlined in existential drama language. Always contemporary "translation".

Keywords: Poetry. Subjectivity. Ferreira Gullar.

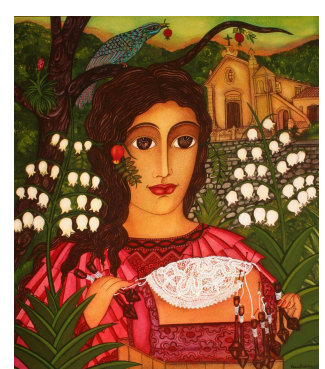

